\title{
Influence of Climate Variability on Seasonal Rainfall Patterns in South-Western DR Congo
}

\section{Kabongo Tshiabukole1 ${ }^{*}$, Pongi Khonde1, Muliele Muku¹, Kizungu Vumilia',2, Kiasala Lunekua1, Mbuya Kankolongo ${ }^{1}$}

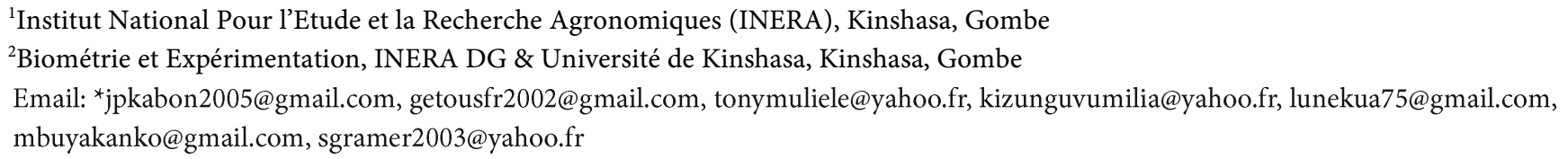

How to cite this paper: Tshiabukole, K., Khonde, P., Muku, M., Vumilia, K., Lunekua, K. and Kankolongo, M. (2016) Influence of Climate Variability on Seasonal Rainfall Patterns in South-Western DR Congo. Open Access Library Journal, 3: e2952. http://dx.doi.org/10.4236/oalib.1102952

Received: September 5, 2016

Accepted: September 25, 2016

Published: September 28, 2016

Copyright $\odot 2016$ by authors and Open Access Library Inc.

This work is licensed under the Creative Commons Attribution International License (CC BY 4.0).

http://creativecommons.org/licenses/by/4.0/

\begin{abstract}
Climate variability in DR Congo in general and in the Kongo Central Province in particular is well established. However, rains related to variables such as frequency of rainy days and duration of the rainy seasons was generally very little studied. This study aims to investigate the influence of the climate event on rainfall patterns in the south-western of the DRC. This is firstly to characterize the climate event from the analysis of the air temperature, the frequency of rainy days and duration of the rainy seasons. Furthermore compare the normal monthly rainfall over the period 19622012 to clear the behavior of seasonal rainfall patterns. Climate variability is manifested by temporal dynamic regressive temperatures, annual rainfall and a decrease in the number of rainy days. A temperature increase of around $1^{\circ} \mathrm{C}$ was observed from 1992 and the thermal peak was recorded in $1994\left(>28^{\circ} \mathrm{C}\right)$. The highest rainfall was recorded in 2006 ( $>2400 \mathrm{~mm})$. These variabilities cause short periods of intense rainfall leading to early droughts of the end of season.
\end{abstract}

\section{Subject Areas}

Environmental Sciences

Keywords

Climate Variability, Rainfall Regime, Drought Index, DR Congo, INERA Mvuazi

\section{Introduction}

In the province of Kongo Central in the Democratic Republic of Congo (DR Congo), rainfall is generally abundant due to the influence of warm winds from the southwest 
and condensation caused by cold currents Benguela [1]. They are short-term and focused on ten days per month and total for the rainy season, an average monthly height of about $130 \mathrm{~mm}$, with a maximum exceeding $230 \mathrm{~mm}$ in December or April. All these supposed phenomena known by locals are very few argued objectively on science. Aguilar et al. [2] state that lack of information on trends in rainfall variables and climate extremes in many regions across the developing world. SOLOMON et al. [3] also believe that the rainfall indexes are still too few studies in sub-Saharan Africa.

Despite the often dramatic consequences of the rainfall fluctuation on agriculture and the environment Mvuazi, variability remains unclear as outliers in its time series. The daily rainfall series analyzed in this area only covers the period 1990-2008 [4]. On the other hand, note that the strong human impact in Mvuazi zone followed by a noticeable degradation of natural resources would only increase this climate variability and/or impacts in the region.

It is therefore necessary to thoroughly analyze the seasonal cycle of Mvuazi rainfall. Indeed, the interest in this type of study lies in the fact that extreme events may become more frequent due to global warming [5] and it is appropriate to consider them now. There is currently a strong scientific interest in the field of analysis of climate extremes because they reflect some important nonlinearity and their economic and social consequences of human activity are potentially huge [6].

This study addresses a characterization of Umbro-thermal Mvuazi events. Thus time series at different time were formed. The results of this study may find direct application locally including demonstrations of erosion phenomena, the landslides, and occurrences of floods and in the context of agriculture-related activities. The study will generate strategies to lead by farmers to consider the notion of seasonal hydrological risks in the development of the agricultural calendar.

\section{Materials and Methods}

\subsection{Data}

The analysis of rainfall and temperature dependence of the INERA Mvuazi station $\left(5^{\circ} 21^{\prime} \mathrm{S}, 14^{\circ} 5^{\prime} \mathrm{E}\right.$ and altitude of $470 \mathrm{~m}$ above sea level) was conducted from rainfall data available daily from 1 January 1962 to 31 December 2012.

\subsection{Approach}

The approach is based on a global study based on statistical methods, and the calculation of the few meteorological indexes.

Analysis of drought by using meteorological drought indexes.

Drought indexes and the most commonly used for monitoring and forecasting tools are following.

\subsection{Gap Index Average (Em)}

The deviation from the average is the difference between the annual amount of precipi- 
tation $(\mathrm{Pi})$ and the average annual precipitation amount $(\mathrm{Pm})$. This is the index most used to estimate the rainfall deficit throughout the year. However, the gap in the middle is the most used by agro meteorologists, obviously, when the data sample is asymmetrical, the difference between the mean and the median is great.

$$
\mathrm{Em}=\mathrm{Pi}-\mathrm{Pm}
$$

The gap is positive for the wet year and negative for the dry year. There is talk of deficit year when rainfall is below average and over-year when the average is exceeded. This index allows visualizing and determining the number of loss-making years and their estate.

\subsection{Compared to Normal Rainfall (RN)}

This index is expressed mathematically as a percentage as follows:

$$
\mathrm{RN}(\%)=(\mathrm{Pi} / \mathrm{Pm}) \times 100
$$

where

Pi: precipitation of the iyear;

Pm: the average precipitation for the same time period studied.

This report makes a point estimate rainfall compared to normal: A year is classified as dry if rainfall is below normal; that is to say when the $\mathrm{RN}$ is less than $100 \%$ [7].

\subsection{Rainfall Deficit Index (IDP) or Index of the Deviation from Normal (En)}

To locate rainfall in a long series of rainfall records, proportional to the average deviation is used. This index (Equation (3)) allows visualizing and determining the number of loss-making years and their estate. A positive value indicates a wet year while a negative value indicates a dry year. The accumulation of years of successive indexes serves to identify the major trends in isolation from small fluctuations from one year to another. When the sum of the differences increases, it is a wet tendency. The trend is a "dry" otherwise.

$$
\operatorname{IDP}(\%)=(\mathrm{Pi}-\mathrm{Pm}) / \mathrm{Pm} \times 100
$$

where:

IDP: rainfall deficit index (percentage).

Pi: annual rainfall $(\mathrm{mm})$.

Pm: average rainfall $(\mathrm{mm})$.

\subsection{Standardized Precipitation Index (SPI)}

Standardized Precipitation Index (SPI) created by MCKEE et al. [8]

$$
\mathrm{SPI}=(\mathrm{Xi}-\mathrm{Xm}) / \mathrm{Si}
$$

where $\mathrm{Xi}$ is the cumulative rainfall for $\mathrm{i}$ year; $\mathrm{Xm}$ and $\mathrm{Si}$ are the mean and the standard deviation of annual rainfall observed for a given set respectively.

Adopted by the World Meteorological Organization (WMO) in 2009 and approved during the Congress World Meteorological Congress in 2011, the standardized precipitation index is a simple, powerful and flexible both based on rainfall data [8] [9] and allow as well checking the periods/dry cycles that periods/dry cycles. SPI compares 
rainfall over a certain period (usually 1 - 24 months) to long-term average rainfall observed on the same site [10] [11] (Table 1).

\section{Results and Discussion}

\subsection{Evolution of Rainfall}

Analysis of the characteristics of rainfall series of Mvuazi (Table 2) shows that they are relatively unbalanced. There is a non-significant difference between positional parameters (mean, median). The gap between the minimum and the maximum is very important. The coefficient of variation (CV) for annual precipitation series is characterized by strong fluctuations. Based on the observed seasonal and annual data, one can notice the irregularities in rainfall and rising trends (Figure 1).

The big trend is clear from the accumulated differences in rainfall (Figure 2) disregarding the slight fluctuations of successive years over the entire period.

According ROGNON [7], a year is classified as dry if rainfall is below normal; that is to say when the $\mathrm{RN}$ is less than $100 \%$. On the last 2 decades only six years $1997 / 98$, 1999/2000, 2000/01, 2007/08, 2010/11, 2012/13 were classified as dry (Figure 3).

Although the trend of rainfall is on the rise, the pace of daily precipitation shows a decrease in the number of days of rainfall from 1999 to 2012. In other words, it rains

Table 1. Values of the SPI.

\begin{tabular}{cc}
\hline from 2.0 to more & Extremely Wetter \\
from 1.5 to 1.99 & Very wet \\
from 1.0 to 1.49 & Moderately moist \\
from -0.99 to 0.99 & Near normal \\
from -1.0 to -1.49 & Moderately dry \\
from -1.5 to -1.99 & Very dry \\
from -2 to less & Extremely dry \\
\hline
\end{tabular}

Table 2. Characteristics of statistical annual rainfall data.

\begin{tabular}{cccc}
\hline Statistics & Annual rainfall $(\mathrm{mm})$ & Season A & SeasonB \\
\hline Means & 1506.3 & 598.2 & 577.3 \\
Minimum & 1029.1 & 314.1 & 360.1 \\
Maximum & 2428.10 & 1228.1 & 802.3 \\
Mediane & 1513.5 & 594.1 & 578.8 \\
Standard deviation & 265.3 & 163.6 & 119.0 \\
Variance & 70,373 & $26,754.1$ & $14,157.7$ \\
Standard error & 37.1 & 22.9 & 16.6 \\
CV (\%) & 17.6 & 27.3 & 20.6 \\
\hline
\end{tabular}

Season A (starts from mid-October to end January) and season B (lasts from mid-March to mid-May). 


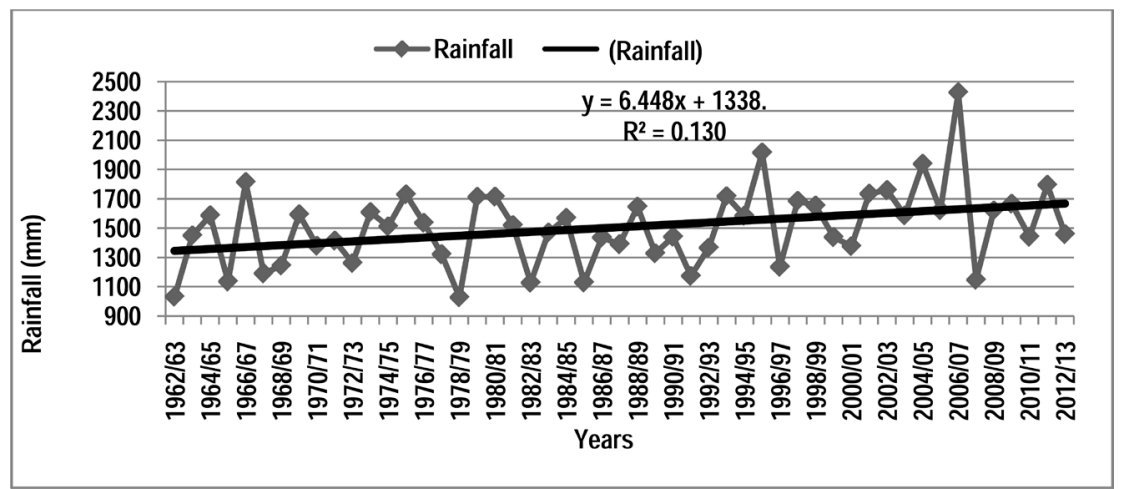

Figure 1. Evolution of annual rainfall in the Mvuazi station from 1962 to 2012.

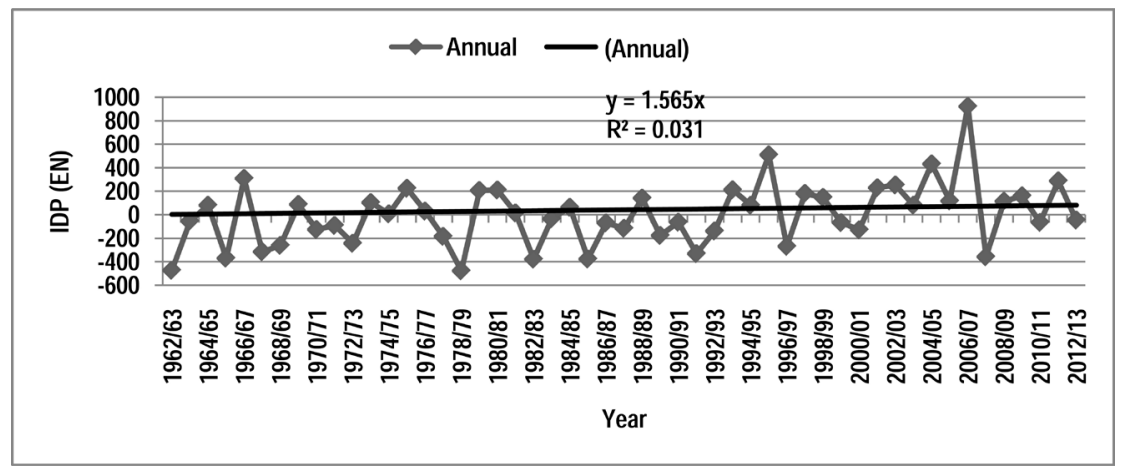

Figure 2. Evolution of the difference cumulative rainfall compared to normal Mvuazi.

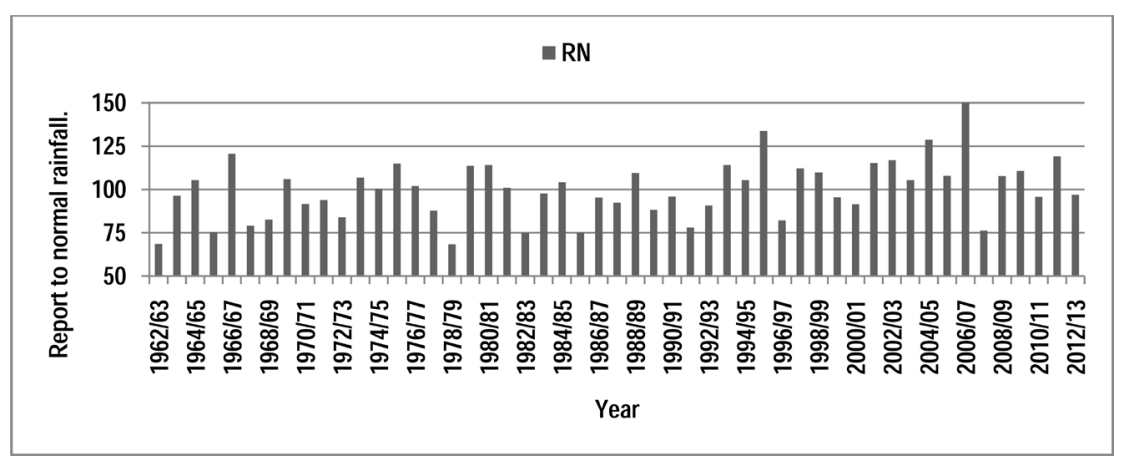

Figure 3. Report to normal rainfall.

heavily but in very short time. This causes the shortening of the rainy season and late season drought (Figure 4).

The most persistent droughts occurred in the early decades, they are formed of two or three consecutive dry years (Figure 5). The difference analysis between dry and wet periods experienced periods presented in Figure 3 can show once again that the Southwest region of the DR Congo undergoes a wet climate change trend. This was predicted by the GIEC [12].

In order to characterize the level of severity of droughts experienced, we relied on the calculation of the index of standardized precipitation (SPI). As a result, the frequency of moderate drought is $18 \%$ while that of severe droughts is $0.2 \%$. 


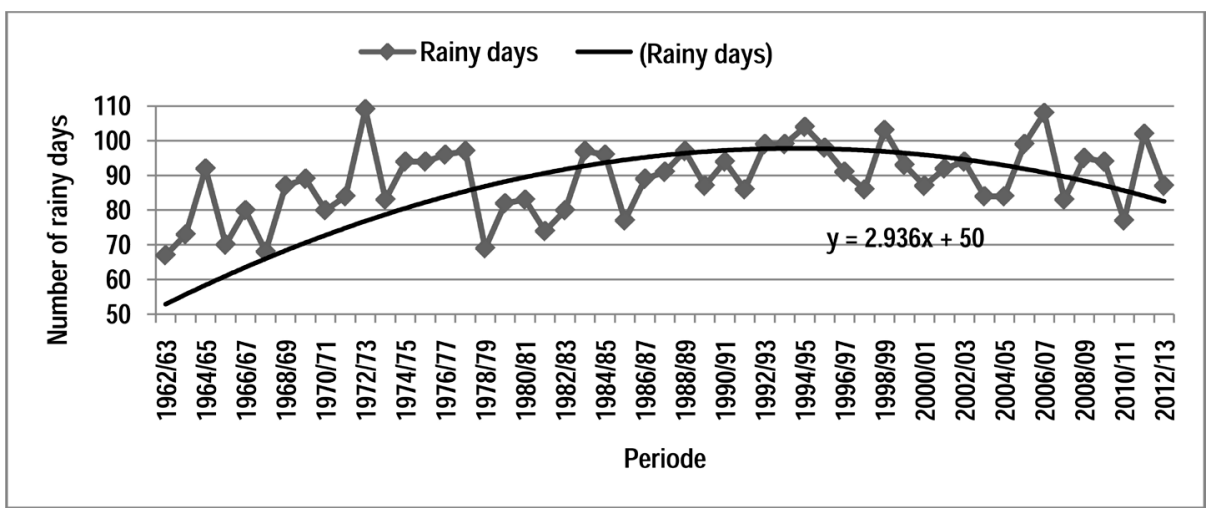

Figure 4. Evolution of the annual number of rainy days.

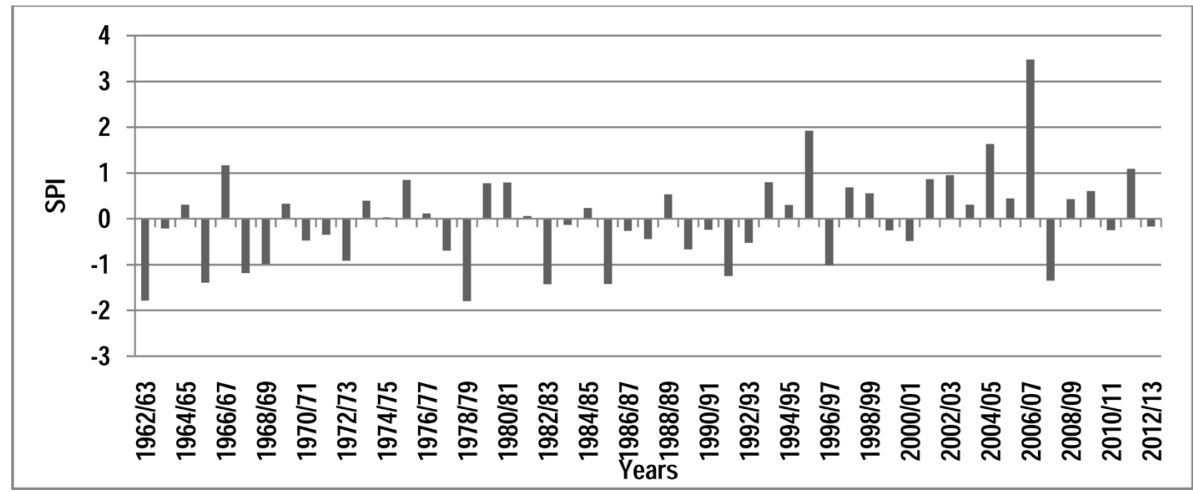

Figure 5. Standardized Precipitation Index (SPI).

The most persistent droughts occurred in the first decades, they consist of two, three and four consecutive dry years (Figure 5 ).

The analysis of different experienced droughts and wet periods presented in Figure 5 can show once again that the South-west region of DR Congo undergoes climate disruption wet trend:

- Before 1994, rainfall was less abundant and well distributed; after 1995, by cons, we had more and more heavy rain for short periods.

- The last two decades have seen a moderate drought, making it the wettest decades.

The succession of dry years is 2 years while that of wet years is 6 years maximum.

\subsection{Temperatures Evolution}

Table 3 on the main characteristics of temperature data sets to Mvuazi station allows highlighting an increase in the average temperature of approximately $1^{\circ} \mathrm{C}$, providing information about the global warming phenomenon [13].

The thermally absolute temperature record was broken in the period (2010 and 2011). This trend is consistent with global warming recorded during the last fifty years with the acceleration of this process during the period 1993-2011 (Figure 6), which was named one of the hottest episodes [13]. 


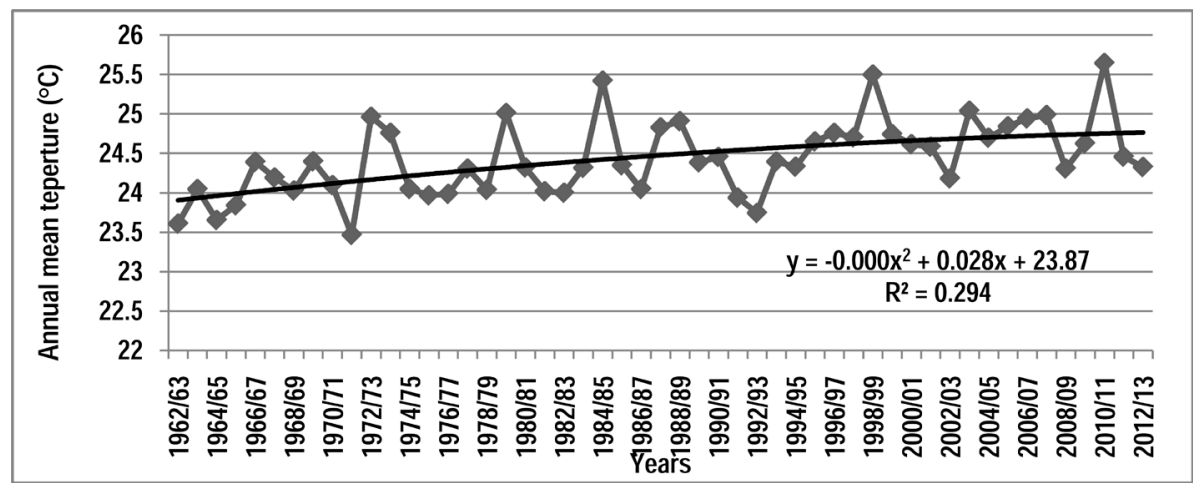

Figure 6. Evolution of the annual average temperature from 1962 to 2012.

Table 3. Statistical characteristics of annual and seasonal average temperatures for the period 1962-2012 to Mvuazi.

\begin{tabular}{cccc}
\hline Statistics & Annual temperature $\left({ }^{\circ} \mathrm{C}\right)$ & Season A & Season B \\
\hline Means & 24.40 & 25.1 & 25.6 \\
Minimum & 23.5 & 28.8 & 24.2 \\
Maximum & 25.6 & 26.4 & 26.8 \\
Mediane & 24.4 & 25.1 & 25.6 \\
Standard deviation & 0.5 & 0.5 & 0.6 \\
Variance & 0.23 & 0.29 & 0.35 \\
Standard error & 0.07 & 0.08 & 0.08 \\
CV (\%) & 2.0 & 2.1 & 2.3 \\
\hline
\end{tabular}

Season A (starts frommid-October to end January) and season B (lasts from midMarch to mid-May).

The study of thermal series shows an asymmetry and a non-significant difference between positional parameters (mean, median). The gap between the minimum and the maximum is very important (Table 3 ).

The annual and seasonal variation coefficient for average temperature series is characterized by a low fluctuation of approximately $4.86 \%, 13.20 \%$ and $5.64 \%$ respectively for the annual, season 1 and season 2; which allows assessing the degree of variability and the dispersion of the values relative to the average.

\section{Conclusions}

Several drought indexes to characterize meteorological drought in the savannah Southwestern DR Congo are proposed in this poster. Based on the analyzes and results presented, based on data from the Mvuazi station, we can remember that the South-western DR Congo is likely to drought to wet dominant trend. Dry years consist of two or three consecutive dry years. Drought can occur throughout the year as it can last two or more consecutive years.

The index standardized precipitation shows that the frequency of occurrence of dry successive years is relatively low: over the last 50 years, 25 have experienced droughts. 
The trend line confirms the general downward trend in the number of rainy days. The trend line average annual temperature confirms a general upward trend, and therefore a significant warming. Shortening periods of rain combined with high intensity rainfall often causes the snap rains causing droughts early end to the season.

\section{References}

[1] PNUD/UNOPS (1998) Monography Bas Congo. Physical Description XXI, 361p.

[2] Aguilar, E., Aziz Barry, A., Brunet, M., Ekang, L., Fernandes, A., Massoukina, M., Mbah, J., Mh Do Nascimento, D.J., Peteson, T.C., Thamba Umba, O., Tomou, M. and Zhang, X. (2009) Change in Temperature and Precipitation Extremes in Western Central Africa. Guinea Conakry, Zimbabwe, 1955-2006. Journal of Geographical Research, 114.

[3] Solomon, S., Qin, D., Manning, M., Alley, R.B., Berntsen, T., Bindoff, N.L., Chen, Z., Chidthaisong, A., Gregory, J.M., Hegerl, G.C., Heimann, M., Hewitson, B., Hoskins, B.J., Joos, F., Jouzel, J., Kattsov, V., Lohmann, U., Matsuno, T., Molina, M., Nicholls, N., Overpeck, J., Raga, G., Ramaswamy, V., Ren, J., Rusticucci, M., Somerville, R., Stocker, T.F., Whetton, P., Wood, R.A. and Wratt, D. (2007) Technical Summary. In: Solomon, S., Qin, D., Manning, M., Chen, Z., Marquis, M., Averyt, K.B., Tignor, M. and Miller, H.L., Eds., Climate Change 2007: The Physical Science Basis. Contribution of Working Group Ito the Fourth Assessment Report of the Intergovernmental Panel on Climate Change, Cambridge University Press, Cambridge and New York.

[4] Wamuini Lunkayilakio, S., Vreven, E., Vandewalle, P., Mutambue, S. and Snoeks, J. (2010) Contribution to the Knowledge of Fish Fauna of Inkisi in Bas-Congo (DR Congo). Cybium, 34, 83-91.

[5] Houghton, J.T.Y., Ding, D.J., Griggs, M., Noguer, P.J., Van Der Linden, X., Dai, K. and Maskell, C.A. (Eds.) (2001) The Scientific Basis: Contribution of Working Group I to the Third Assessment Report of the Intergovernmental Panel on Climate Change. Climate Change, Cambridge University Press, 525-582.

[6] Naveau, P., Nogaja, M., Ammann, C., Yiou, P., Cooley, D. and Jomelli, V. (2005) Statistical Methods for the Analysis of Geophysical Extreme Events. Comptes Rendus de l'Académie des Sciences, 337, 1013-1022. http://dx.doi.org/10.1016/j.crte.2005.04.015

[7] Rognon, P. (1997) Drought and Aridity: Their Impact on Desertification in North Africa. Sécheresse, 7, 287-297.

[8] Mckee, T.B., Doesken, N.J. and Kleist, J. (1993) The Relationship of Drought Frequency and Duration Times Scales. American Meteorological Society. 8 th Conference on Applied Climatology, 17-22 Janvier, Anaheim, 179-184.

[9] Mckee, T.B., Doesken, N.J. and Kleist, J. (1995) Drought Monitoring with Multiple Times Scales. American Meteorological Society. 9th Conference on Applied Climatology, 15-22 Janvier, Dallas, 233-236.

[10] Edwards, D.C. and Mckee, T.B. (1997) Characteristics of 20th Century Drought in the United States at Multiple Time Scales. Climatology Report Number 97-2, Colorado State University, Fort Collins.

[11] Guttman, N.B. (1994) On the Sensitivity of Sample L Moments to Sample Size. Journal of Climatology, 7, 1026-1029. http://dx.doi.org/10.1175/1520-0442(1994)007<1026:OTSOSL >2.0.CO;2

[12] GIEC (2007) Assessment Climate Change 2007: The Physical Science Basis. In Quatrième rapport d'évaluation de GIEC. 2 février 2007, France. 
[13] IPCC, Climate Change 2001 and 2007: Impacts, Adaptation and Vulnerability. Contribution of Working Group II to the Third Assessment Report of the IPCC. In: McCarthy, J.J., Canziani, O.F., Leary, N.A., Dokken, D.J. and White, K.S., Eds., Cambridge University Press, $1032 \mathrm{p}$.

Submit or recommend next manuscript to OALib Journal and we will provide best service for you:

- Publication frequency: Monthly

- 9 subject areas of science, technology and medicine

- Fair and rigorous peer-review system

- Fast publication process

- Article promotion in various social networking sites (LinkedIn, Facebook, Twitter, etc.)

- Maximum dissemination of your research work

Submit Your Paper Online: Click Here to Submit

Or Contact service@oalib.com 